\title{
Impact of maintenance of Macrobrachium rosenbergii De Man, 1879 (Crustacea, Decapoda, Palaemonidae) broodstock on the water used in culture ponds
}

\author{
Biudes JFV. , Camargo, AFM..$^{a, b *}$ and Henares, MNP. ${ }^{a}$ \\ ${ }^{a}$ Centro de Aquicultura, Universidade Estadual Paulista - UNESP, CEP 14884-900, Jaboticabal, SP, Brazil \\ ${ }^{b}$ Departamento de Ecologia, Universidade Estadual Paulista - UNESP, CEP 13506-900, Rio Claro, SP, Brazil \\ *e-mail: afmc@rc.unesp.br
}

Received July 8, 2010 - Accepted October 14, 2010 - Distributed November 30, 2011

(With 2 figures)

\begin{abstract}
Aquaculture production generates social and economic benefits, but can also cause environmental impacts. The objectives of this study were: a) to characterise the impacts caused by the maintenance of broodstock of the giant river prawn (Macrobrachium rosenbergii) on the physical and chemical characteristics of the water used in culture ponds, and b) to evaluate the relationship between the biomass of the prawns and the impact of culture on the water used in the ponds. Between January and December 2004, we determined, monthly, the biomass of M. rosenbergii by means of biometrics, and the physical and chemical variables of the supply and effluent water from a pond used to maintain breeding stock. The results showed that the effluent water had higher contents of chlorophyll- $a$, suspended particulate matter (SPM), pH, dissolved oxygen, total Kjeldahl nitrogen (TKN) and dissolved Kjeldahl nitrogen (DKN), inorganic nitrogen (IN), total (TP) and dissolved phosphorus (DP), and P-orthophosphate than the supply water. The highest biomass of $M$. rosenbergii occurred in April $\left(127.0 \mathrm{~g} . \mathrm{m}^{-2}\right)$ and the lowest in August $\left(71.5 \mathrm{~g} . \mathrm{m}^{-2}\right)$, and there were positive linear correlations between the biomass of the prawns and the intensity of the increases in TKN, DKN, IN, TP, and $\mathrm{DP}$ of the water used in the pond. The maintenance of broodstock of $M$. rosenbergii increased the chlorophyll- $a$, SPM, nitrogen, and phosphorus contents of the water in the pond. Additionally, the increase in the biomass of the prawns intensifies the export of nitrogen and phosphorus from the pond in the effluent.
\end{abstract}

Keywords: biomass, giant river prawn, effluent, phosphorus, nitrogen.

\section{Impacto da manutenção de reprodutores de Macrobrachium rosenbergii De Man, 1879 (Crustacea, Decapoda, Palaemonidae) na água utilizada nos viveiros de cultivo}

\begin{abstract}
Resumo
A produção aquícola gera benefícios sociais e econômicos, no entanto, também pode proporcionar impactos ambientais. Os objetivos deste trabalho foram: a) caracterizar os impactos causados pela manutenção de reprodutores do camarãoda-malásia (Macrobrachium rosenbergii) nas características físicas e químicas da água utilizada nos viveiros de cultivo; e b) avaliar a relação entre a biomassa de camarões e o impacto do cultivo na água utilizada no viveiro. Entre janeiro e dezembro de 2004, foram determinadas, mensalmente, a biomassa de M. rosenbergii, por meio de biometria, e as variáveis físicas e químicas da água de abastecimento e do efluente de um viveiro utilizado para a manutenção de reprodutores. Os resultados mostraram que o efluente possui maiores valores de clorofila $a$, material particulado em suspensão (MPS), pH, oxigênio dissolvido, nitrogênio Kjeldahl total (NKT) e nitrogênio Kjeldahl dissolvido (NKD), nitrogênio inorgânico (NI), fósforo (PT) e fósforo dissolvido (PD) e P-ortofosfato do que a água de abastecimento do viveiro. A maior biomassa de $M$. rosenbergii ocorreu em abril $\left(127,0 \mathrm{~g} . \mathrm{m}^{-2}\right)$ e a menor em agosto $\left(71,5 \mathrm{~g} . \mathrm{m}^{-2}\right)$ e houve correlações lineares positivas entre a biomassa de camarões e a intensidade do aumento de NKT, NKD, NI, PT e PD da água utilizada no viveiro. A manutenção de reprodutores de M. rosenbergii aumentou a clorofila- $a$, MPS, nitrogênio e fósforo da água utilizada no viveiro. Além disso, o aumento da biomassa de camarões intensifica a exportação de nitrogênio e fósforo do viveiro pelo efluente.
\end{abstract}

Palavras-chave: biomassa, camarão-da-malásia, efluente, fósforo, nitrogênio. 


\section{Introduction}

World production of the giant river prawn (Macrobrachium rosenbergii De Man, 1879) has grown considerably in recent years, mainly in Asian countries (New, 2005). According to the FAO (2009), world production of M. rosenbergii rose from 62,557 to 213,274 tons between 1997 and 2007. In Brazil, 230 tons were produced in 2007 (FAO, 2009). This growth in world production is due principally to the development of culture technologies (Valenti and Tidwell, 2006), and has brought economic and social benefits to those involved in the production network.

On the other hand, prawn farming can also produce negative environmental impacts, mainly related to the effluent from culture ponds (Boyd, 2000). Different studies on culture ponds of marine shrimps have shown that the effluents from these ponds are enriched in nitrogen, phosphorus, and organic matter (Lin et al., 2005; CasillasHernández et al., 2006; Anh et al., 2010). These effluents are generally discharged untreated into aquatic environments and contribute to the process of artificial eutrophication, which causes changes in the biodiversity and the physical and chemical characteristics of the water in the environments that receive these effluents (Beardmore et al., 1997). In addition, the eutrophication increases the cost of treating the water for human consumption because of the need to use more sophisticated technologies to remove organic matter, nutrients, pathogenic organisms, and other impurities from the water (Tundisi and Tundisi, 2008).

The characteristics of aquaculture effluents can vary with the species cultured, the intensity of culture, management of feed, and level of technology used (Boyd, 2000). Therefore, the characterisation of the impact of each cultured organism on the water used depends on individualised evaluations. Evaluation of this impact is fundamental for improving the culture management, with a view toward producing effluent with lower concentrations of nitrogen, phosphorus, suspended particulate matter, and biochemical oxygen demand (Baccarin and Camargo, 2005). In addition, it is important to know the impacts of aquaculture on the water that is used, in order to determine the need for treatment of the effluent and the type of treatment required to improve the quality of the effluent produced (Jones et al., 2001). Although the impact of aquaculture is well known, this impact can only be assessed if we estimate the nutrient loads as measured in mass per unit of time. Thus in this study, the loads of nitrogen and phosphorus of the supply and effluent water of the rearing pond were calculated, in order to allow comparison of the impact of maintaining broodstock of $M$. rosenbergii with those of other culture systems and organisms.

The objectives of this study were a) to characterise the impacts caused by the maintenance of Macrobrachium rosenbergii broodstock on the physical and chemical characteristics of the water used in the ponds in terms of load, and b) to evaluate the relationship between the biomass of prawns and the impact of this culture on the water used in the pond.

\section{Material and Methods}

The study was carried out at the UNESP Aquaculture Center Carciniculture division (CAUNESP), in Jaboticabal, São Paulo, Brazil (21 ${ }^{\circ} 15^{\prime} \mathrm{S}$ and $\left.48^{\circ} 19^{\prime} \mathrm{W}\right)$, between January 2004 and December 2004. The culture pond used to maintain broodstock of Macrobrachium rosenbergii has cement walls and a capacity of $220 \mathrm{~m}^{3}\left(200 \mathrm{~m}^{2}\right.$ surface area and $1.1 \mathrm{~m}$ depth). Before the beginning of the study, the pond was drained and dried in the air, and limed with agricultural limestone (1000 kg.ha- $\left.{ }^{-1}\right)$. In December 2003 the pond was filled with water and stocked with 720 brood prawns of the species $M$. rosenbergii, with a mean weight of $27.0 \pm 5.2$ g.individual $^{-1}\left(97.2\right.$ g. $\left.\mathrm{m}^{-2}\right)$. The water supplying the pond came from reservoirs, and the flow rate at the pond entrance was adjusted to $16.0 \pm 1 \mathrm{~L} \cdot \mathrm{min}^{-1}$. The flow rate of the effluent at the pond outlet was $15.0 \pm 1 \mathrm{~L} \cdot \mathrm{min}^{-1}$. Under these conditions, the daily removal rate of the total volume of the pond was approximately $10 \%$, and the retention time of the water was approximately 10 days.

The prawns were fed daily, at 8:00 AM and 5:00 PM, with Laguna ${ }^{\circledR}$ CRS-38 commercial feed from Socil, in pelletised form. On days when the water temperature was lower than $18{ }^{\circ} \mathrm{C}$, the prawns were not fed. The composition of the feed used is $37 \%$ crude protein (minimum), $7 \%$ ether extract (minimum), $7 \%$ crude fibre (maximum), 14\% mineral matter (maximum), 1\% phosphorus (minimum), and $11 \%$ water (maximum). The amount of feed provided daily was equivalent to $4 \%$ of the total biomass of the $M$. rosenbergii broodstock in the pond.

On the first day of each month, 50 prawns from the pond were weighed to estimate their biomass $\left(\mathrm{g} . \mathrm{m}^{-2}\right)$ and to adjust the amount of feed supplied $\left(\mathrm{g}^{\mathrm{d}} \mathrm{day}^{-1}\right)$. The total number of prawns in the pond was determined in April, August, and December 2004, when the prawns were removed and all the individuals were counted. To estimate the number of prawns in the other months, a mortality rate of $1 \%$ per week was used. During the study, no new prawns were added, and therefore, the variation in biomass during the study was due exclusively to mortality and to growth of the prawns stocked in the pond.

On the $11^{\text {th }}$ day of each month, at 10:00 AM, we collected 1-L samples of the supply and effluent water of the pond. In parallel, we measured the temperature, $\mathrm{pH}$, and dissolved oxygen (dissolved $\mathrm{O}_{2}$ ) in the supply and effluent water, using a multiparameter analyser (Horiba model U-10).

Approximately $0.5 \mathrm{~L}$ of each water sample was filtered in a Whatman GF/C glass fibre filter (porosity $0.45 \mathrm{~mm}$, diameter $47 \mathrm{~mm}$ ), for determination of the concentrations of suspended particulate matter (SPM) (APHA, 1998), chlorophyll- $a$ (Nush, 1980), ammoniacal nitrogen (N-ammoniacal) (Koroleff, 1976), dissolved Kjeldahl nitrogen (DKN), $\mathrm{N}$-nitrate $\left(\mathrm{N}-\mathrm{NO}_{3}\right), \mathrm{N}$-nitrite $\left(\mathrm{N}-\mathrm{NO}_{2}\right)$ (Mackereth et al., 1978), dissolved phosphorus (DP), and P-orthophosphate (P$\mathrm{PO}_{4}$ ) (Golterman et al., 1978). The unfiltered samples were used for the determination of the concentrations of 
total Kjeldahl nitrogen (TKN) (Mackereth et al., 1978) and total phosphorus (TP) (Golterman et al., 1978). The concentration of inorganic nitrogen (IN) of each sample was calculated from the sum of the concentrations of $\mathrm{N}$-ammoniacal, $\mathrm{N}-\mathrm{NO}_{3}$, and $\mathrm{N}-\mathrm{NO}_{2}$.

Each month, we calculated the loads $\left(\mathrm{g} . d a y^{-1}\right)$ of TKN, DKN, IN, TP, DP, P-PO , and SPM of the supply and effluent water. Subsequently, we calculated the additions (g.day ${ }^{-1}$ ) (Equations 1 and 2).

$\mathrm{L}=[\mathrm{C}] * \mathrm{Q}$

where, $\mathrm{L}=$ load of the forms of $\mathrm{N}, \mathrm{P}$, or SMP; $[C]=$ concentration of the forms of $\mathrm{N}, \mathrm{P}$, or SPM; $\mathrm{Q}=$ flow of the supply or effluent water.

$\mathrm{A}=\mathrm{Le}-\mathrm{Ls}$

where, $\mathrm{A}=$ addition; $\mathrm{Le}=$ load of the forms of $\mathrm{N}, \mathrm{P}$, or SPM in the pond effluent; Ls = load of the forms of N, P, or SPM in the pond supply water.

The Principal Components Analysis (PCA) (Bouroche and Saporta, 1982) was applied to ordinate the collections carried out at the two sampling points (supply and effluent water of the rearing pond) in the twelve months of the year, considering the values of temperature, chlorophyll- $a, \mathrm{pH}$, and the concentrations of dissolved $\mathrm{O}_{2}, \mathrm{TKN}, \mathrm{DKN}$, IN, TP, DP, $\mathrm{P}_{-} \mathrm{PO}_{4}$, and SPM, as environmental descriptors. Linear regression analysis (Zar, 1998) was used to show the variation of the additions of TKN, DKN, IN, TP, DP, $\mathrm{P}-\mathrm{PO}_{4}$, and SPM in the water used in the culture pond, as a function of the biomass of prawns in the pond. Statistical analyses were carried out with the program Statistica, version 7.1 (Statsoft, 2005).

\section{Results}

The first two principal components explained $85.64 \%$ of the variability of the data for temperature, chlorophyll- $a$, SPM, pH, dissolved $\mathrm{O}_{2}$, TKN, DKN, IN, TP, DP, and $\mathrm{P}_{-} \mathrm{PO}_{4}$ of the supply and effluent water of the culture pond. Component 1 explained $72.77 \%$ of the total variance, and component 2 explained $12.87 \%$. The $\mathrm{pH}$, dissolved $\mathrm{O}_{2}$, chlorophyll- $a$, SPM, TKN, DKN, IN, TP, DP, and P-PO showed a negative correlation with component 1 , and temperature showed a positive correlation with component 2 (Table 1). In Figure 1, the data of 12 monthly samples of effluent formed a group located on the left side of the PCA, whereas the 12 monthly samples of supply water formed another group on the right side. Therefore, the effluent showed higher levels of chlorophyll- $a$, SPM, $\mathrm{pH}$, dissolved $\mathrm{O}_{2}$, TKN, DKN, IN, TP, DP, and $\mathrm{P}_{-} \mathrm{PO}_{4}$ than the supply water. The monthly mean, maximum, and minimum values of temperature, chlorophyll- $a, \mathrm{SPM}, \mathrm{pH}$, dissolved $\mathrm{O}_{2}$, TKN, DKN, IN, TP, DP, and P-PO of the supply and effluent water are shown in Table 2. All forms of nitrogen and phosphorus had higher concentrations in the effluent than in the supply water. For example, the concentration of TP in the effluent (102.2 mg.L $\left.\mathrm{L}^{-1}\right)$ was higher than in the supply water (43.5 mg. $\left.\mathrm{L}^{-1}\right)$.

The biomass of $M$. rosenbergii was highest in April (1270 g.m ${ }^{-2}$ ) and lowest in August (71.5 g.m ${ }^{-2}$ ). The quantity of feed provided was highest in April (5.07 g. day $\left.^{-1} \cdot \mathrm{m}^{-2}\right)$ and lowest in July $\left(2.46\right.$ g.day ${ }^{-1} \cdot \mathrm{m}^{-2}$ ) (Table 3$)$. The increase in the biomass of $M$. rosenbergii caused linear increases in the additions of TKN, DKN, IN, TP, and DP in the water used in the culture pond (Figure 2). On the other hand, the linear regression analysis did not show a relationship between the prawn biomass and the additions of $\mathrm{P}-\mathrm{PO}_{4}$ and SPM in the water.

Table 1. Correlation of temperature, chlorophyll $a$, suspended particulate matter (SPM), $\mathrm{pH}$, dissolved $\mathrm{O}_{2}$ (dissolved oxygen), total Kjeldahl nitrogen (TKN), dissolved Kjeldahl nitrogen (DKN), inorganic nitrogen (IN), total phosphorus (TP), dissolved phosphorus (DP), and P-orthophosphate (P$\mathrm{PO}_{4}$ ) of the water with components 1 and 2 of the PCA.

\begin{tabular}{|c|c|c|}
\hline Variables & Component 1 & Component 2 \\
\hline Temperature & 0.10605 & -0.90506 \\
\hline Chlorophyll- $a$ & -0.65436 & -0.33984 \\
\hline SPM & -0.92808 & 0.27552 \\
\hline $\mathrm{pH}$ & -0.82657 & -0.19245 \\
\hline Dissolved $\mathrm{O}_{2}$ & -0.65788 & 0.51643 \\
\hline TKN & -0.97089 & -0.01242 \\
\hline DKN & -0.94442 & 0.02587 \\
\hline IN & -0.96677 & 0.10375 \\
\hline TP & -0.97515 & 0.12016 \\
\hline DP & -0.97923 & -0.06427 \\
\hline $\mathrm{PO}_{4}-\mathrm{P}$ & -0.86269 & -0.21349 \\
\hline Variation explained & $72.77 \%$ & $12.87 \%$ \\
\hline
\end{tabular}

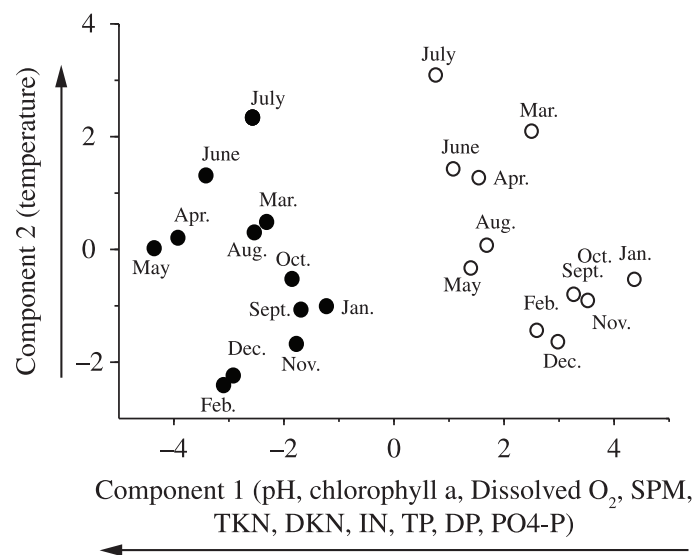

Figure 1. PCA ordination of the supply water $(\circ)$ and effluent water $(\bullet)$ of the rearing pond in the 12 months of the study, as a function of the values of temperature, chlorophyll- $a, \mathrm{pH}$, dissolved oxygen, suspended particulate matter, total Kjeldahl nitrogen, dissolved Kjeldahl nitrogen, inorganic nitrogen, total phosphorus, dissolved phosphorus, and $\mathrm{P}$-orthophosphate. 
Table 2. Monthly mean, minimum, and maximum values of temperature, chlorophyll- $a$, suspended particulate matter (SPM), $\mathrm{pH}$, dissolved $\mathrm{O}_{2}$ (dissolved oxygen), total Kjeldahl nitrogen (TKN), dissolved Kjeldahl nitrogen (DKN), inorganic nitrogen (IN), total phosphorus (TP), dissolved phosphorus (DP), and P-orthophosphate ( $\left.\mathrm{P}-\mathrm{PO}_{4}\right)$.

\begin{tabular}{|c|c|c|c|c|c|c|}
\hline \multirow{2}{*}{ Variables } & \multicolumn{3}{|c|}{ Supply water } & \multicolumn{3}{|c|}{ Effluent water } \\
\hline & Minimum & Mean & Maximum & Minimum & Mean & Maximum \\
\hline Temperature $\left({ }^{\circ} \mathrm{C}\right)$ & 23.7 & 25.5 & 26.9 & 23.3 & 25.7 & 28.3 \\
\hline Chlorophyll- $a\left(\mathrm{mg} . \mathrm{L}^{-1}\right)$ & 2 & 5.9 & 9.8 & 8.5 & 13.5 & 20.5 \\
\hline $\operatorname{SPM}\left(\mathrm{mg} \cdot \mathrm{L}^{-1}\right)$ & 17.0 & 28.1 & 41.0 & 40.0 & 47.8 & 58.7 \\
\hline $\mathrm{pH}$ & 6.70 & 7.08 & 7.39 & 7.22 & 7.52 & 8.00 \\
\hline Dissolved $\mathrm{O}_{2}\left(\mathrm{mg} \cdot \mathrm{L}^{-1}\right)$ & 5.9 & 6.5 & 7.6 & 6.5 & 7.2 & 8.2 \\
\hline TKN (mg.L-1) & 246.2 & 305.3 & 400.0 & 475.5 & 517.2 & 541.6 \\
\hline DKN (mg.L-1) & 109.2 & 140.1 & 189.1 & 186.4 & 204.2 & 262.9 \\
\hline IN (mg.L $\left.{ }^{-1}\right)$ & 33.8 & 51.7 & 73.1 & 84.2 & 107.2 & 136.0 \\
\hline TP (mg.L $\left.\mathrm{L}^{-1}\right)$ & 20.6 & 43.5 & 81.5 & 85.2 & 102.2 & 131.6 \\
\hline $\mathrm{DP}\left(\mathrm{mg} \cdot \mathrm{L}^{-1}\right)$ & 12.6 & 19.8 & 23.6 & 35.7 & 39.2 & 46.6 \\
\hline $\mathrm{PO}_{4}-\mathrm{P}\left(\mathrm{mg} \cdot \mathrm{L}^{-1}\right)$ & 6.8 & 13.1 & 19.2 & 15.0 & 28.0 & 32.4 \\
\hline
\end{tabular}

Table 3. Biomass of prawns, amount of feed provided, and additions of the forms of nitrogen and phosphorus and SPM in the water used in the rearing pond holding broodstock of Macrobrachium rosenbergii, in each month of the year.

\begin{tabular}{|c|c|c|c|c|c|c|c|c|c|c|c|c|}
\hline & Jan. & Feb. & Mar. & Apr. & May & June & July & Aug. & Sept. & Oct. & Nov. & Dec. \\
\hline Biomass (g.m ${ }^{-2}$ ) & 99.0 & 93.5 & 110.0 & 127.0 & 121.3 & 92.8 & 72.5 & 71.5 & 82.6 & 88.0 & 91.8 & 96.5 \\
\hline Feed $\left(\right.$ g.day $\left.^{-1} \cdot \mathrm{m}^{-2}\right)$ & 3.96 & 3.74 & 4.40 & 5.07 & 4.96 & 3.15 & 2.46 & 2.57 & 3.30 & 3.52 & 3.67 & 3.86 \\
\hline TKN (g.day $\left.{ }^{-1}\right)$ & 4.97 & 4.92 & 5.45 & 5.81 & 5.42 & 3.89 & 3.15 & 2.82 & 4.21 & 3.72 & 4.67 & 4.25 \\
\hline DKN (g.day $\left.{ }^{-1}\right)$ & 1.45 & 1.38 & 1.32 & 1.49 & 1.55 & 1.18 & 1.05 & 1.15 & 1.32 & 1.20 & 1.37 & 1.40 \\
\hline IN $\left(\right.$ g.day $\left.^{-1}\right)$ & 1.05 & 1.38 & 1.28 & 1.57 & 1.35 & 1.07 & 0.87 & 1.02 & 1.12 & 1.29 & 1.22 & 1.32 \\
\hline TP $\left(\right.$ g.day $\left.^{-1}\right)$ & 1.37 & 1.25 & 1.38 & 1.53 & 1.65 & 1.27 & 0.95 & 1.11 & 1.30 & 1.27 & 1.20 & 1.08 \\
\hline DP $\left(\right.$ g.day $\left.^{-1}\right)$ & 0.47 & 0.37 & 0.43 & 0.53 & 0.50 & 0.37 & 0.27 & 0.31 & 0.38 & 0.43 & 0.43 & 0.50 \\
\hline $\mathrm{PO}_{4}-\mathrm{P}\left(\right.$ g.day $\left.^{-1}\right)$ & 0.36 & 0.36 & 0.17 & 0.27 & 0.38 & 0.32 & 0.23 & 0.26 & 0.35 & 0.39 & 0.32 & 0.39 \\
\hline SPM (g.day ${ }^{-1}$ ) & 475 & 525 & 425 & 410 & 489 & 312 & 216 & 331 & 446 & 489 & 460 & 505 \\
\hline
\end{tabular}

\section{Discussion}

The maintenance of broodstock of Macrobrachium rosenbergii at biomass levels between 71.5 and 127.0 g.m ${ }^{-2}$ increased the contents of suspended particulate matter (SPM) and chlorophyll $a$ in the water used in the culture pond. The increase in SPM is probably related to the production of feces and excretions by $M$. rosenbergii, the production of detritus, and the growth of phytoplankton in the pond. Some fraction of the feed consumed by the cultured organisms is eliminated as excretions or feces (Anh et al., 2010). An additional part of the feed is not consumed and becomes detritus (Hargreaves, 1998). With respect to the phytoplankton, the results for chlorophyll- $a$ showed that there was an increase in phytoplankton in the pond, probably because of the increases in concentrations of IN and $\mathrm{P}-\mathrm{PO}_{4}$ in the water. These nutrients are considered to be limiting factors for phytoplankton growth (Burford, 1997).

The increases in $\mathrm{pH}$ and dissolved $\mathrm{O}_{2}$ concentrations are probably related to photosynthesis by the phytoplankton. We note that the $\mathrm{pH}$ and dissolved $\mathrm{O}_{2}$ were measured at
10:00 AM, after at least three hours of sunlight to allow photosynthesis. If the measurements had been made at night, the lack of photosynthesis might have resulted in lower levels of $\mathrm{pH}$ and dissolved $\mathrm{O}_{2}$ in the effluent of the rearing pond. Oxygen levels can show wide daily variations in prawn-culture ponds, reaching saturation rates higher than $180 \%$ at 3:00 PM, and less than 70\% at 06:00 AM (Henry-Silva et al., 2010). We also note that the $\mathrm{pH}$ values obtained in this study (6.7 to 8.0) were, most of the time, within the range (7.0 to 8.5 ) that is recommended as ideal for the health and development of $M$. rosenbergii (Boyd and Zimmerman, 2000). The levels of dissolved $\mathrm{O}_{2}$ were always above $2 \mathrm{mg} . \mathrm{L}^{-1}$, the level below which $M$. rosenbergii becomes stressed, according to Avault (1986).

The maintenance of broodstock of $M$. rosenbergii between the biomasses of 71.5 and 127.0 g.m ${ }^{-2}$ increased the concentrations of TKN, DKN, IN, TP, DP, and P-PO in the water used in the culture pond. This increase is related to the non-use by $M$. rosenbergii of the $\mathrm{N}$ and $\mathrm{P}$ present in the feed. Part of the $\mathrm{N}$ and $\mathrm{P}$ present in the 

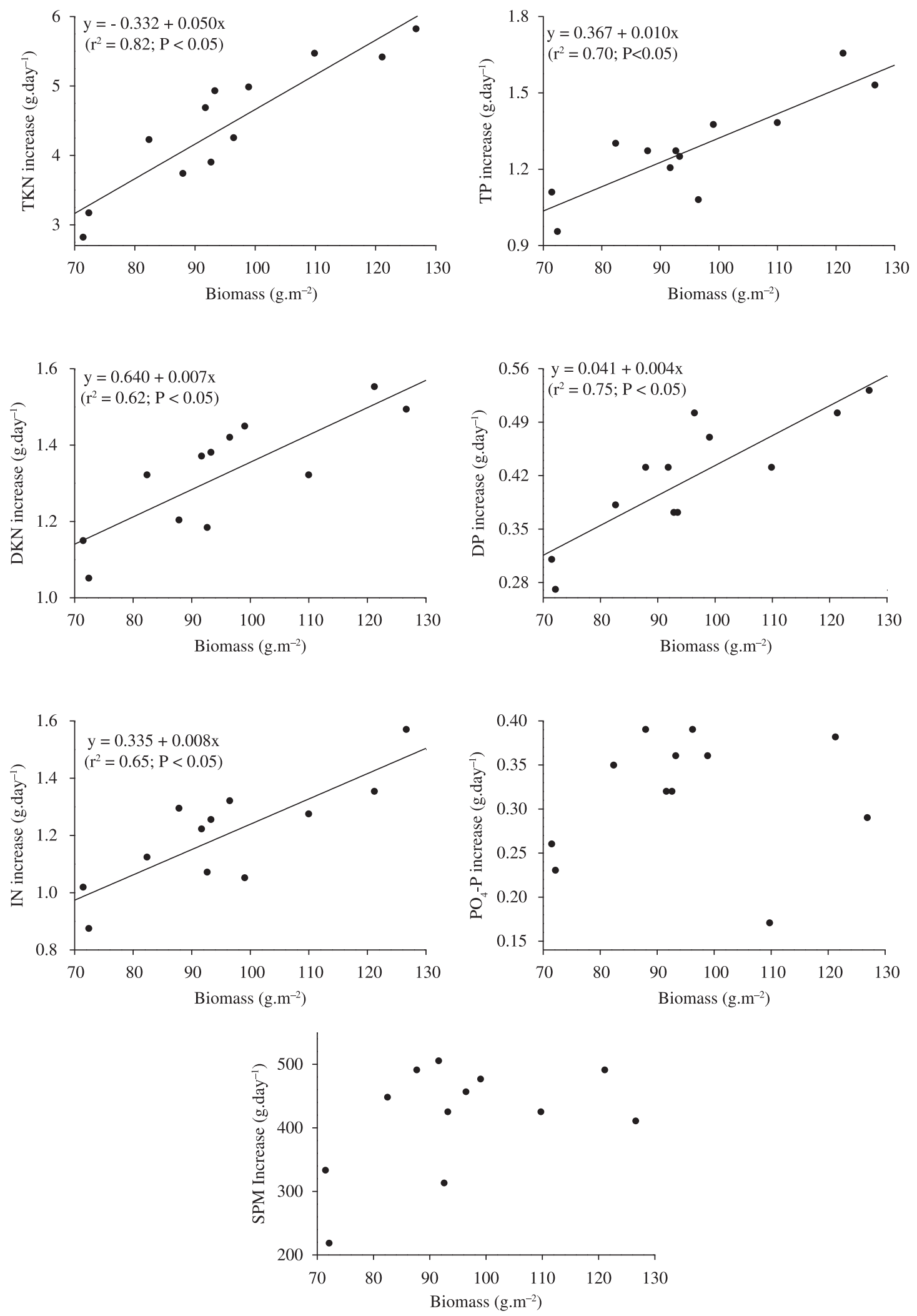

Figure 2. Effect of the biomass of Macrobrachium rosenbergii on the additions of total Kjehldahl nitrogen (TKN), dissolved Kjeldahl nitrogen (DKN), inorganic nitrogen (IN), total phosphorus (TP), dissolved phosphorus (DP), P-orthophosphate (P$\mathrm{PO}_{4}$ ), and suspended particulate matter (SPM) in the water used in the rearing pond. 
Table 4. Values of the concentrations of total Kjeldahl nitrogen (TKN) and total phosphorus (TP) of the supply and effluent water of culture ponds of different species.

\begin{tabular}{|c|c|c|c|c|c|c|}
\hline \multirow[b]{2}{*}{ Species } & \multicolumn{2}{|c|}{ Supply water } & \multicolumn{2}{|c|}{ Effluent water } & \multirow[b]{2}{*}{$\begin{array}{l}\text { Density } \\
\left(\text { g.m }{ }^{-2}\right)\end{array}$} & \multirow[b]{2}{*}{ References } \\
\hline & $\begin{array}{c}\text { TKN } \\
\left(\mu \mathbf{g . L ^ { - 1 }}\right)\end{array}$ & $\begin{array}{c}\text { TP } \\
\left(\mu \mathbf{g} . \mathbf{L}^{-1}\right)\end{array}$ & $\begin{array}{c}\text { TKN } \\
\left(\mu \mathbf{g} . \mathbf{L}^{-1}\right)\end{array}$ & $\begin{array}{c}\mathbf{T P} \\
\left(\mu \mathrm{g} . \mathbf{L}^{-1}\right)\end{array}$ & & \\
\hline Macrobrachium amazonicum & 300 & 128 & 470 & 229 & 82 & $\begin{array}{l}\text { Henry-Silva and } \\
\text { Camargo (2008) }\end{array}$ \\
\hline Oreochromis niloticus & 320 & 17 & 420 & 60 & 595 & $\begin{array}{c}\text { Baccarin and Camargo } \\
(2005)\end{array}$ \\
\hline Macrobrachium rosenbergii & 305 & 43 & 517 & 102 & $71-127$ & This study \\
\hline
\end{tabular}

diet consumed is eliminated into the water in excretions and feces (Biudes et al., 2009). Nitrogen is excreted by $M$. rosenbergii mainly as ammonia (45 to $78 \%$ ) and, in smaller quantities, as nitrite, nitrate, and water-soluble organic forms (urea, amino acids, and uric acid) (Chen and Kou, 1996). Unconsumed feed also contributes to the increases in $\mathrm{N}$ and $\mathrm{P}$ in the water, because the decomposition of this feed releases soluble forms of $\mathrm{N}$ (e.g., nitrite, nitrate, ammonia, amino acids) and P (e.g., orthophosphates, phosphoproteins, phospholipids) (Mires, 1995). In addition, the movements of the prawns on the bottom of the ponds contributes to the resuspension into the water column of detritus (e.g., feed, dead plankton, clay), which contains $\mathrm{N}$ and $\mathrm{P}$ in its constitution (Hargreaves, 1998).

Many studies have shown that aquaculture causes impacts on water from the addition of nutrients (CasillasHernández et al., 2006; Henry-Silva and Camargo, 2006; Sindilaru et al., 2009; Anh et al., 2010). However, it is not easy to quantitatively compare the results of these studies and to indicate how the species cultivated or the management techniques used add more nutrients to the pond water. One difficulty in this comparison is that the studies frequently show only the values of nutrient concentrations in the supply water and the effluent. Table 4 lists the concentrations of TKN and TP in the supply water and effluent in ponds used to raise several species. From these data, it is possible to conclude only that the cultivation of $M$. rosenbergii, Macrobrachium amazonicum (Heller, 1862), and Oreochromis niloticus (Linnaeus, 1758) increased the NKT and PT concentrations of the effluent, because the values of these variables were higher in the effluent than in the supply water. A precise comparison of the impact caused by cultivation is only possible if we calculate the nutrient loads, i.e., the quantity (mass) of nutrients per unit of time.

The increase in the biomass of $M$. rosenbergii intensified the increases of TKN, DKN, IN, TP, and DP in the pond water. There was a positive relationship between the biomass of prawns and the amount of feed provided, and, according to Casillas-Hernández et al. (2006), the feed is the principal source of water pollution from the culture. Therefore, the increase of the biomass of $M$. rosenbergii can affect the water quality of the culture. Consequently, the increase in the biomass must occur together with the treatment of the pond effluent, to remove $\mathrm{N}$ and $\mathrm{P}$ from the effluent and minimise the impact of the discharge of this effluent into receiving waterbodies. According to Lin et al. (2005) and Henry-Silva and Camargo (2008), artificially constructed wetlands populated with aquatic macrophytes are capable of removing $\mathrm{N}$ and $\mathrm{P}$ from the effluent of shrimp aquaculture ponds, and are therefore an alternative for treatment of the effluent. The use of sedimentation ponds also allows removal of $\mathrm{N}$ and $\mathrm{P}$ from shrimp-culture affluents (Henry-Silva and Camargo, 2008). In a study carried out during fattening of $O$. niloticus, Baccarin and Camargo (2005) also found a positive relationship between the biomass of the fish and the concentrations of nitrogen and phosphorus in the effluent.

\section{Conclusions}

The maintenance of broodstock of Macrobrachium rosenbergii at biomasses between 71.5 and 127.0 g.m ${ }^{-2}$ increased the levels of chlorophyll- $a$, SPM, nitrogen, and phosphorus in the water used in the rearing pond.

Calculation of the nutrient load of the supply and effluent water of rearing ponds is essential for the comparison of the impact of different culture systems and species, because it takes into account both the outflow rate and the concentration. The use of concentration is inadequate for the comparison in the impact of different culture systems, because it varies with the outflow.

There was a direct positive relationship between the biomass of the broodstock of $M$. rosenbergii and the increases of TKN, DKN, IN, TP, and DP in the water used in the rearing pond.

Acknowledgements - The authors thank FAPESP for financial support (Processes: 04/06962-0 and 03/09589-5), Dr. Wagner Cotroni Valenti for logistical support during the course of the study, and Carlos Fernando Sanches for help in the field and laboratory work.

\section{References}

ANH, PT., KROEZE, C., BUSH, SR. and MOL, APJ., 2010. Water pollution by intensive brackish shrimp farming in southeast Vietnam: Causes and options for control. Agricultural Water Management, vol. 97, p. 872-882. http://dx.doi.org/10.1016/j. agwat.2010.01.018 
American Public Health Association - APHA, 1998. Standard methods for the examination of water and wastewater. $20 \mathrm{nd}$ ed. Washington: APHA. 937 p.

AVAULT, JW., 1986. Seven years of pond research with the prawn Macrobrachium rosenbergii in Louisiana. Aquaculture Management, vol. 12, no. 4, p. 51-54.

BACCARIN, AE. and CAMARGO, AFM., 2005. Characterization and evaluation of the impact of feed management on the effluents of Nile tilapia (Oreochromis niloticus) culture. Brazilian Archives of Biology and Technology, vol. 48, no. 1, p. 81-90. http://dx.doi. org/10.1590/S1516-89132005000100012

BEARDMORE, JA., MAIR, GC. and LEWIS, RI., 1997. Biodiversity in aquatic systems in relation to aquaculture. Aquaculture Research, vol. 28, no. 10, p. 829-839. http://dx.doi. org/10.1111/j.1365-2109.1997.tb01007.x

BIUDES, JFV., PEZZATO, LE. and CAMARGO, AFM., 2009. Digestibilidade aparente da farinha do aguapé (Eichhornia crassipes) pela tilápia-do-nilo. Revista Brasileira de Zootecnia, vol. 38 , no. 11, p. 2079-2085.

BOUROCHE, JM. and SAPORTA, G., 1982. Análise de dados. Rio de Janeiro: Zahar.

BOYD, CE., 2000. Water quality: An introduction. Norwell: Kluwer Academic Publishers. 330 p.

-, 2003. Guidelines for aquaculture effluent management at the farm-level. Aquaculture, vol. 226, no. 1-4, p. 101-112. http:// dx.doi.org/10.1016/S0044-8486(03)00471-X

BOYD, CE. and ZIMMERMANN, S., 2000. Grow-out systems: water quality and soil management. In: NEW, MB. and VALENTI, WC. (Eds.). Freshwater prawn farming: The farming of Macrobrachium rosenbergii. Oxford: Blackwell Science. p. 221-228.

BURFORD, M., 1997. Phytoplankton dynamics in shrimp ponds. Aquaculture Research, vol. 28, no. 5, p. 351-360. http://dx.doi. org/10.1111/j.1365-2109.1997.tb01052.x

CASILLAS-HERNÁNDEZ, R., MAGALLÓN-BARAJAS, F., PORTILLO-CLARCK, G. and PÁEZ-OSUNA, F., 2006. Nutrient mass balances in semi-intensive shrimp ponds from Sonora, Mexico using two feeding strategies: Trays and mechanical dispersal. Aquaculture, vol. 258, no. 1-4, p. 289-298. http://dx.doi. org/10.1016/j.aquaculture.2006.03.027

CHEN, JC. and KOU, CT., 1996. Nitrogenous excretion in Macrobrachium rosenbergii at different $\mathrm{pH}$ levels. Aquaculture, vol. 144 , no. 1-3, p. 155-164.

Food and Agriculture Organization of the United Nations FAO, 2009. FISHSTAT Plus: Universal software for fishery statistical time series. Version 2.3. Available from: $<$ http://www. fao.org >. Accessed in: 02 mar. 2010.

GOLTERMAN, HL., CLYNO, RS. and OHNSTAD, MAM., 1978. Methods for physical and chemical analysis of freshwaters. 2nd ed. Oxford: Blackwell. 213 p.

HARGREAVES, JA., 1998. Nitrogen biogeochemistry of aquaculture ponds. Aquaculture, vol. 166, no. 3-4, p. 181-212. http://dx.doi.org/10.1016/S0044-8486(98)00298-1
HENRY-SILVA, GG. and CAMARGO, AFM., 2006. Efficiency of aquatic macrophytes to treat Nile tilapia pond effluents. Scientia Agricola, vol. 63, no. 5, p.433-438.

-, 2008. Tratamento de efluentes de carcinicultura por macrófitas aquáticas flutuantes. Revista Brasileira de Zootecnia, vol. 37, no. 2, p. 181-188.

HENRY-SILVA, GG., CAMARGO, AFM., PONTES, CS. and MIYASE, LK., 2010. Características limnológicas da coluna d'água e dos efluentes de viveiros de criação de camarões-da-amazônia. Revista Brasileira de Zootecnia, vol. 39, no. 10, p. 2099-2107.

JONES, AB., DENNISON, WC. and PRESTON, NP., 2001. Integrated treatment of shrimp effluent by sedimentation, oyster filtration and macroalgal absorption: A laboratory scale study. Aquaculture, vol. 193, no. 1-2, p. 155-178.

KOROLEFF, F., 1976. Determination of nutrients. In: GRASSHOFF, K. (Ed.). Methods of seawater analysis. New York: Verlag Chemie Weinhein. p. 117-181.

LIN, YF., JING, SR., LEE, DY., CHANG, YF., CHEN, YM. and SHIH, KC., 2005. Performance of a constructed wetland treating intensive shrimp aquaculture wastewater under high hydraulic loading rate. Environmental Pollution, vol. 134, no. 3, p. 411-421. PMid:15620586. http://dx.doi.org/10.1016/j.envpol.2004.09.015

MACKERETH, FIF., HERON, J. and TALLING, JF., 1978. Water analysis: Some revised methods for limnologists. London: Freshwater Biological Association, 121p.

MIRES, D., 1995. Aquaculture and the aquatic environment: mutual impact and preventive management. Israeli Journal of Aquaculture, vol. 47, p. 163-172.

NEW, MB., 2005. Freshwater prawn farming: global status, recent research and glance at the future. Aquaculture Research, vol. 36, no. 3, p. 210-230. http://dx.doi.org/10.1111/j.13652109.2005.01237.x

NUSH, EA., 1980. Comparison of different methods for Chlorophyll and phaeopigments determination. Archiv für Hydrobiologie, vol. 14 , no. 1, p. 14-36.

SINDILARU, PD., REITER, R. and WEDEKIND, H., 2009. Impact of trout aquaculture on water quality and farm effluent treatment options. Aquatic Living Resource, vol. 22, no. 1, p. 93103. http://dx.doi.org/10.1051/alr/2009009

Statsoft Inc., 2005. Statistica (data analysis software system). Version 7.1. Statsoft Inc

TUNDISI, JG. and TUNDISI, TM., 2008. Limnologia. São Paulo: Oficina de Textos. 631p.

VALENTI, WC. and TIDWELL, JH., 2006. Economics and management of freshwater prawn culture in Western Hemisphere. In: LEUNG, PS. and ENGLE, C. (Eds.). Shrimp culture: Economics, market, and trade. Oxford: Blackwell Science. p. 263-278.

ZAR, JH., 1998. Biostatistical analysis. 4nd ed. Upper Saddle River: Prentice Hall. 929 p. 
